\title{
An Original Study on the Correlations Between Magnesium and Depression and Their Cardiovascular Relevance
}

\author{
CRISTIAN STATESCU ${ }^{1}$, CEZAR HONCERIU2*, RAMONA NICULINA JURCAU3 ${ }^{3}$, CONSTANTIN TRUS ${ }^{4}$ \\ ${ }^{1}$ Grigore T. Popa University of Medicine and Pharmacy, 16 Universitatii Str., 700115 lasi, Romania \\ ${ }^{2}$ Alexandru loan Cuza University, 11 Carol I, Blvd., 700506 lasi, Romania \\ 3 Iuliu Hatieganu University of Medicine and Pharmacy of Cluj-Napoca, Faculty of Medicine, Department of Pathophysiology, \\ 8 V. Babes, Str., 400012 Cluj-Napoca, Romania \\ ${ }^{4}$ Dunarea de J os University, Faculty of Medicine, Department of Morphological and Functional Sciences, 47 Domneasca Str., \\ 800008 Galati, Romania
}

\begin{abstract}
With magnesium being an essential element in the human body, we are proposing here an original study on the correlations between magnesium and depression and their cardiovascular relevance in this context, by the usage of the experimental forced swim test. Thus, the data we are presented here could have an increased relevance in the management of these disorders, and in the further understanding of the biochemical magnesium supplementation.
\end{abstract}

Keywords: magnesium, depression, oxidative stress, cardiovascular

Magnesium is considered to be an essential element in the human body. Over the years it has been found that magnesium regulates a vast number of biochemical processes [1]. An optimal level of magnesium leads to a proper functioning of the majority of human organs [2]. Regarding the levels of magnesium in the human body, it is approximately $24-35 \mathrm{~g}$ of magnesium in an adult individual [3]. The vast majority of the magnesium is deposited in bones (approximatively $60 \%$ ), followed by the muscular tissue (approximatively 20\%) [4].

Other several tissues contain magnesium as well. For example the extracellular fluid contains only $1 \%$ of the total body magnesium [5]. Therefore, magnesium plays a vital role in countless mechanism in the human body. We emphasize here that magnesium is an important factor for hundreds of enzymes, it partakes in the cell cycle, metabolism of carbohydrates, proteins, fats, nucleic acids. Furthermore, the magnesium has an important role in the permeability of the cell membrane, in the cell signaling and migration [5-7]. Other benefits of an optimal level of magnesium include an improved neuromuscular transmission, bone mineralization, blood glucose control and a better regulation of one's blood pressure. It is important to be mentioned that these benefits of magnesium are closely related to that of calcium and potassium, since it is required for the active transport of their ions through cell membranes [8-10]. However, perhaps the most important role of magnesium is its modulatory role in the central nervous system [11].

As previous mentioned, ithas been found that an optimal magnesium level in the human body is vital for the normal functioning of the central nervous system [12]. The available literature states that although higher consumption of magnesium does not protect an individual against the development of a depressive disorder, a very low magnesium intake may be a cause of an increased risk of depression [13].

The results regarding the influence of the magnesium level on depression levels are much clearer in the animal models. These results show that a reduced magnesium intake with an everyday diet resulted in depression- like behaviors in rats [14]. These findings of pre-clinical studies have clearly indicated an antidepressant role of magnesium that was observed after both acute and chronic administration.

The majority of these results were obtained in the forced swim test and in the tail suspension test. In the forced swimming test, also known as the Porsolt test [15], a mouse or a rat is placed in a cylinder of water from which it cannot escape, and after an initial battle, swim and climbing; the animal presents a floating and immobile posture. Immobility in the forced swim model was interpreted as an expression of behavioral despair or entrapment $[16,17]$ and is reversed by the acute administration of almostall available antidepressants. The mostimportant strength of this model is its ability to quickly examine new agents and the phenotype of genetically manipulated mice, and can successfully reduce errors in subjective evaluation.

The available literature shows that the antidepressant potential of magnesium in the forced swim test is comparable to the effect observed for the conventional treatment. In addition, the final results of the test are not influenced by changes in spontaneous locomotor activity of the tested animals [18, 19]. Furthermore, the administration of magnesium has been shown to improve post-traumatic depression in rats [20], or to reverse depression symptoms induced by social isolation in mice [21]. The animals spent less time immobile after placing them in water and presented intensified grooming behavior in the splash test. In addition, the antidepressant activity of magnesium was also demonstrated in other animal models of depression, such as the chronic mild stress model [22].

\section{Experimental part \\ Methods}

The experiments were carried out on male Wistar rats (180-220 g). The animals were kept on a natural day-night cycle with free access to food and water. Each experimental group consisted of 8 animals. We had 5 experimental groups: one control group, one group that received $7.5 \mathrm{mg} / \mathrm{kg}$ of magnesium, one group that received $15 \mathrm{mg} / \mathrm{kg}$ of magnesium, one group that received $30 \mathrm{mg} /$

\footnotetext{
* email: chonceri@yahoo.fr
} 
$\mathrm{kg}$ and one group that received the maximum dosage of $50 \mathrm{mg} / \mathrm{kg}$ of magnesium. Magnesium was administered intraperitoneally. Control animals received injections of saline (vehicle). The aforementioned dosages were selected using previously published reports regarding magnesium's effect on depression in animal models.

Total magnesium concentration in serum was determined by xylidyl blue method. Serum was separated by centrifugation at $5,000 \times \mathrm{g}$ for $10 \mathrm{~min}$ at $4^{\circ} \mathrm{C}, 1 \mathrm{~h}$ after collection and coagulation of trunk blood, and stored at $-20^{\circ} \mathrm{C}$ until analysis. $10 \mathrm{ml}$ of thawed serum was added to $1 \mathrm{~mL}$ of the commercially available reagent and the absorbance of the solution was read at $520 \mathrm{~nm}$ in a spectrophotometer. Magnesium concentrations were calculated as $\mathrm{mg} / 100 \mathrm{~mL}$.

Our experiment in the forced swim test was conducted according to the method of Porsolt et al [22]. The rats were placed individually in glass cylinders ( $45 \mathrm{~cm}$ high, $25 \mathrm{~cm}$ in diameter) containing $30 \mathrm{~cm}$ of water, maintained at room temperature during testing $\left(25 \pm 1.0^{\circ} \mathrm{C}\right)$. Afterwards, the rats were removed and returned to their home cages after 15 min in water. They were again placed in the cylinder 24 $\mathrm{h}$ later. The total duration of immobility in rats was measured during a $5 \mathrm{~min}$ test. The rats were judged to be immobile when they remained floating passively in the water.

Romanian and the European laws on animal use in biomedical research were considered in animal care and experimental procedures. All efforts were made in order to reduce animal suffering.

The obtained data were evaluated by the one-way analysis of variance (ANOVA), followed by post hoc multiple comparisons test. All results are presented as the means \pm SD. A difference between experimental groups was considered significant when $p<0.05$.

\section{Results and discussions}

When we compared all the 5 groups, there was significant difference between them regarding the duration of immobility, $F(1,4)=65.585, p<0.001$.

Post hoc comparisons between groups showed a significant difference regarding the duration of immobility between control and the group that received $15 \mathrm{mg} / \mathrm{kg}$ of magnesium ( $p<0.001)$, control and the group which received $30 \mathrm{mg} / \mathrm{kg}$ of magnesium $(p<0.001)$, control and the group which received $50 \mathrm{mg} / \mathrm{kg}$ of magnesium ( $p<$ 0.001 ). No significant difference regarding the immobility time was found between the control group and the group which received $7.5 \mathrm{mg} / \mathrm{kg}$ of magnesium $(p=0.801)$. Other statistically significant difference were found between the

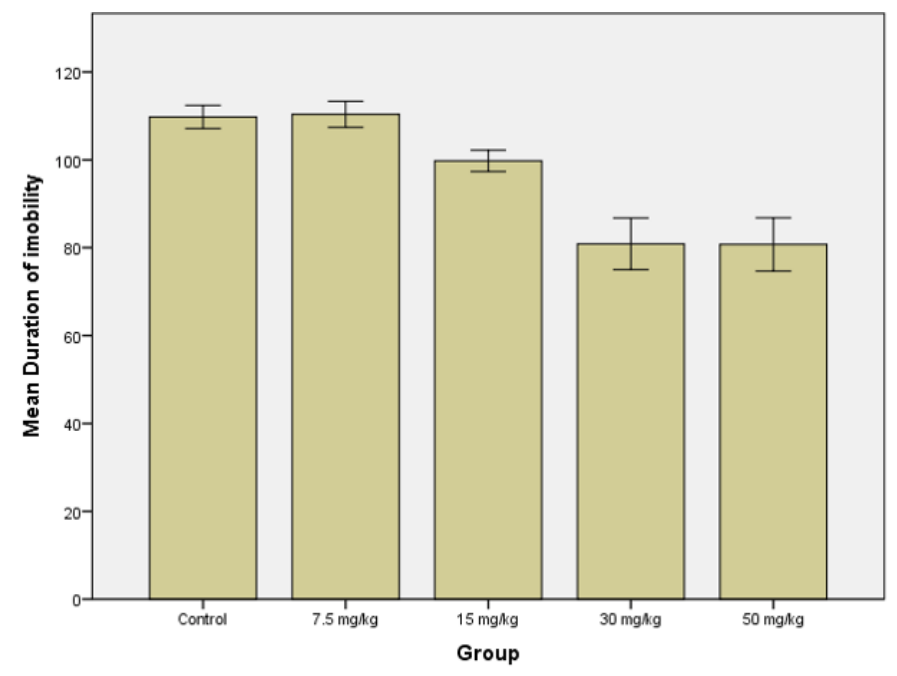

group of rats which received $7.5 \mathrm{mg} / \mathrm{kg}$ of magnesium and the group which received $15 \mathrm{mg} / \mathrm{kg}(\mathrm{p}<0.001)$, between the group of rats which received $7.5 \mathrm{mg} / \mathrm{kg}$ of magnesium and the group which received $30 \mathrm{mg} / \mathrm{kg}(\mathrm{p}<0.001)$, between the group of rats which received $7.5 \mathrm{mg} / \mathrm{kg}$ of magnesium and the group which received $50 \mathrm{mg} / \mathrm{kg}$ ( $\mathrm{p}<$ 0.001 ), between the group of rats which received $15 \mathrm{mg} /$ $\mathrm{kg}$ of magnesium and the group which received $30 \mathrm{mg} / \mathrm{kg}$ $(p<0.001)$, between the group of rats which received 15 $\mathrm{mg} / \mathrm{kg}$ of magnesium and the group which received 50 $\mathrm{mg} / \mathrm{kg}(\mathrm{p}<0.001)$. However, no significant difference was found between the group that received $30 \mathrm{mg} / \mathrm{kg}$ and the group that received $50 \mathrm{mg} / \mathrm{kg}(p=0.962)$.

The first objective of our study was to validate the hypothesis according to which the administration of magnesium will decrease depression symptoms, measured as time of immobility in the forced swim test in our sample of rats. The results obtained after statistically analyzing our data, showed that the rats from the control group presented a significantly longer duration of the immobility when compared to the groups that received 15 $\mathrm{mg} / \mathrm{kg}$, the group that received $30 \mathrm{mg} / \mathrm{kg}$ or the group that received the maximum dosage of $50 \mathrm{mg} / \mathrm{kg}$ magnesium. The only non-significant difference between the control group and one of the other groups was showed by our post hoc analysis regarding the control rats and the rats that received the lowest dosage of magnesium $(7.5 \mathrm{mg} / \mathrm{kg})$. To be more precise, the rats in control group had a mean duration of immobility of 109.75 seconds, whilst the group of rats that received the lowest dosage of magnesium from our experiment $(7.5 \mathrm{mg} / \mathrm{kg})$ had a mean duration of immobility of 110.38 seconds. Therefore, the results presented by our study suggest that a minimum dosage of magnesium exists in order to see a significant improvement in depression-like symptoms in the forced swim models for rats.

The second objective of our study was to determine if an optimal dose-response of magnesium exists for reducing the duration of immobility in the forced swim test. Our results suggest that, at least in our sample of rats, an optimal dose-response appears to exist. As before mentioned a dose of $7.5 \mathrm{mg} / \mathrm{kg}$ was too low to generate any significant response in the duration of immobility of the rats. The significant improvements were observed starting with the dose of $15 \mathrm{mg} / \mathrm{kg}$, and continued with the doses of $15 \mathrm{mg} /$ $\mathrm{kg}$ and $30 \mathrm{mg} / \mathrm{kg}$ of magnesium. The interesting results from our post hoc analysis showed that these improvements stopped at $30 \mathrm{mg} / \mathrm{kg}$ of magnesium. No significant improvement in the depression-like symptoms in our animal model was observed between the group of

Fig 1. The differences regarding the duration of immobility between the 5 experimental groups 
rats that received $30 \mathrm{mg} / \mathrm{kg}$ of magnesium and the rats that received a higher dose of $50 \mathrm{mg} / \mathrm{kg}$. Precisely, the rats that received a dose of $30 \mathrm{mg} / \mathrm{kg}$ of magnesium had a mean duration of immobility of 80.88 seconds, whilst the group of rats that received the highest dosage of magnesium from our experiment $(50 \mathrm{mg} / \mathrm{kg}$ ) had a mean duration of immobility of 80.75 seconds These findings suggest that an optimal dose-response of magnesium for reducing the duration of immobility of rats in the forced swim test exists and it is around $30 \mathrm{mg} / \mathrm{kg}$.

Therefore, an involvement of magnesium in the pathophysiology and treatment of depression is likely and has been previously suggested. Studies available in the literature show that depressed patients display a lower level of magnesium plasma. Furthermore, the same studies show that the same patients increase their magnesium level during recovery $[23,24]$. The results are also similar in the animal models of depression. It has been demonstrated in various animal models that magnesium possesses the antidepressant-like effects. Regarding the results of our study, they are in concordance with those found in the literature. In these studies it has been showed that magnesium significantly reduces the immobility time in the forced swim test, and that these improvements are similar to those found in the imipramine treatment [25]. Regarding the optimal dosage for maximum response, available literature suggests that magnesium has an optimal antidepressant-like effect in the forced swim test in mice, when given at the dose $20-30 \mathrm{mg} / \mathrm{kg}$ [26].

Our present study indicates that magnesium reduces the immobility time of rats in the forced swim test. However, a minimum dosage seems to exist and it should be around $15 \mathrm{mg} / \mathrm{kg}$. Furthermore, a maximum dosage also appears to exist. In our sample of rats, the significant improvements in the depression-like behavior ceased at $30 \mathrm{mg} / \mathrm{kg}$, suggesting that a dose of $50 \mathrm{mg} / \mathrm{kg}$ has no further benefits in reducing depression symptoms in the forced swim test compared to $30 \mathrm{mg} / \mathrm{kg}$ of magnesium.

As previously described by our group, these data presented here could exhibit an important matter on the management of the cardiovascular disorders also, since it was previously show ed, by authors such Rosique-Esteban [27], Efstratiadis [28] and Dinicolantonio [29] that Magnesium will descrease the risk for ischemic heart disease and coronary heart disease, diminishing also other factors such diabetes, hypertension, metabolic syndrome [27-29].

Also there seems to be a correlation also between depression and the cardiovascular risk factors, with an extensive review for example by the Dhar et al [30] in 2016 stating that some biological mechanism of these disorders are intricate in a very complex way, being again related to commune risk factors such as hypertension, diabetes mellitus, and cigarette smoking and suggesting some commune ways to tackle the path physiological mechanisms of both these disorders. This could have of course an increased relevance for the management of both depression and the cardiovascular disorders.

\section{Conclusions}

Thus, we are proposing here an original study on the correlations between magnesium and depression and their cardiovascular relevance in this context, by the usage of the experimental forced swim test specific task in rats. The final data we are showing here could have an increased relevance in the management of these disorders, and in the further understanding of their mechanisms and the biochemical magnesium supplementation.

\section{References}

1. HAGLIN, L., TORNKVIST, B., BACKMAN, L., Acta Diabetologica, 44, no. 3, 2007, p. 138.

2. JORGENSEN, S., OLESEN, M., GUDMAND-HOYER, E., Scandinavian Journal Gastroenterology, 32, no. 4, 1997, p. 334.

3. BLOOMBERG, R.D., FLEISMAN, A., NALLE, J.E. et al, Obes Surg., 15, 2005, p. 145.

4. ***Food and Agriculture Organization/World Health Organization. Vitamin and Mineral Requirements in Human Nutrition, 2nd ed. Geneva: Food and Agriculture Organization/ World Health Organization; 2004, p. 217.

5. ***Food and Nutrition Board, Institute of Medicine. Dietary Reference Intakes for Calcium, Phosphorus,Magnesium, Vitamin D, and Fluoride. Washington DC: National Academy Press; 1997, p. 190. 6. MOSHFEGH, A., GOLDMAN, J., AHUJA, J., RODES, D., LACOMB, R., What We Eat in America, NHANES 2005-2006: Usual Nutrient Intakes from Food and Water Compared to 1997 Dietary Reference Intakes for Vitamin D, Calcium, Phosphorus, and Magnesium. US Department of Agriculture, Agricultural Research Service; 2009. Available at: http:/ /www.ars.usda.gov/ba/bhnrc/fsrg. Accessed November 2009.

7. MA, J., FOLSOM, A.R., MELNICK, S.L. et al, J Clin Epidemiol, 48, no. 7, 1995, p. 927

8. ABBOTT, R.D., ANDO, F., MASAKI, K.H. et al, American J Cardiology, 92, no. 6, 2003, p. 665

9. TOUYZ, R.M., Mol Aspects Med., 24, 2003, p. 107.

10. RUDE, R.K., SINGER, F.R., GRUBER, H.E., J Am Coll Nutrition, 28, no. 2, 2009, p. 131.

11. RUDE, R.K., SHILS, M.E., Magnesium. in: SHILS, M.E.,, SHIKE, M., ROSS, A.C., CABALLERO, B., COUSINS, R.J ., eds. Modern nutrition in health and disease, 10th ed. Baltimore: Lippincott Williams $\&$ Wilkins, 2006, p. 223.

12. PAPADOPOL, V., TUCHENDRIA, E., PALAMARU, I., Magnesium Research, 14, no. 1-2, 2001, p. 27.

13. DEROM, M.L., MARTINEZ-GONZALEZ, M.A., SAYON-OREA, M.C., BES-RASTROLLO, M., BEUNZA, J.] ., SANCHEZ-VILLEGAS, A., J ournal Nutrition, 142, 2012, p. 1053.

14. SINGEWALD, N., SINNER, C., HETZENAUER, A., SARTORI, S.B., MURCK, H., Neuropharmacology, 47, no. 8, 2004, p. 1189.

15. PORSOLT, R.D., LE PICHON, M., JALFRE, M., Nature, 266, 1977, p. 730.

16.CRYAN. J.F., MOMBEREAU, C., VASSOUT, A., Neuroscience Biobehavioral Reviews, 29, no. 4-5, 2005, p. 571.

17. LUCKI, I., DALVI, A., MAYORGA, A.J., Psychopharmacology (Berl), 155, no. 3, 2001, p. 315.

18. DECOLLOGNE, S., TOMAS, A., LECERF, C., ADAMOWICZ, E., SEMAN, M., Pharmacol Biochem Behavior, 58, no. 1, 1997, p. 261.

19. POLESZAK, E., WLAZ, P., KEDZIERSKA, E. et al, Pharmacol Reports, 57, no. 5, 2005, p. 654.

20. FROMM, L., HEATH, D.L., VINK, R., NIMMO, A.J., Journal of the American College Nutrition, 23, no. 5, 2004, p. 529S.

21. HAJ-MIRZAIAN, A., AMIRI, S., KORDJAZY, N., et al, European J Pharmacology, 750, 2015, p. 160.

22. POCHWAT, B., SOWA-KUCMA, M., KOTARSKA, K., MISZTAK, P., NOWAK, G., SZEWCZYK, B., Psychopharmacology, 232, no. 2, 2015, p. 355.

23. HASHIZUME, N., MORI, M., Japanese Journal of Medicine, 129, no. 4,1990, p. 368

24. FRIZEL, D., COPPEN, A., MARKS, V., Br J Psychiatry, 115, 1969, p. 1375.

25. DECOLLOGNE, S., TOMAS, A., LECERF, C., ADAMOWICZ, E., SEMAN, M., Pharmacol Biochem Behav, 58, no. 1, 1997, p. 261.

26. POLESZAK, E., SZEWCZYK, B., KEDZIERSKA, E., WLAY, P., PILC, A., NOWAK, G., Pharmacol Biochem Behav, 78, 2004, p. 7.

27. ROSIQUE-ESTEBAN, N., GUASCH-FERRE, M., HERNANDEZALONSO, P., SALAS-SALVADO, J., Nutrients, 10, no. 2, 2018, p. 168.

28. EFSTRATIADIS, G., SARIGIANNI, M., GOUGOURELAS, I., Hippokratia, 10, no. 4, 2006, p.147.

29. DINICOLANTONIO, J.J ., LIU, J., O'KEEFE, J.H., Open Heart, 5, no. 2, 2018, UNSP e000775.

30. DHAR, A.K., BARTON, D.A., Frontiers Psychiatry, 7, 2016, p. 33.

Manuscript received: 12.11 .2019 